\title{
Differential effects of habitat isolation and landscape composition on wasps, bees, and their enemies
}

\author{
Christof Schüepp • John D. Herrmann • \\ Felix Herzog • Martin H. Schmidt-Entling
}

Received: 14 January 2010/ Accepted: 27 June 2010/Published online: 21 August 2010

(C) Springer-Verlag 2010

\begin{abstract}
Habitat loss and fragmentation are major threats to biodiversity and ecosystem functioning. Effects of these usually intercorrelated processes on biodiversity have rarely been separated at a landscape scale. We studied the independent effects of amount of woody habitat in the landscape and three levels of isolation from the next woody habitat (patch isolation) on trap nesting bees, wasps, and their enemies at 30 farmland sites in the Swiss plateau. Species richness of wasps was negatively affected by patch isolation and positively affected by the amount of woody habitat in the landscape. In contrast, species richness of bees was neither influenced by patch isolation nor by landscape composition. Isolation from woody habitats reduced species richness and abundance of natural enemies more strongly than of their hosts, so that parasitism rate was lowered by half in isolated sites compared to forest edges. Thus, population regulation of the hosts may be weakened by habitat fragmentation. We conclude that habitat amount at the landscape scale and local patch connectivity are simultaneously important for biodiversity conservation.
\end{abstract}

Communicated by Roland Brandl.

Electronic supplementary material The online version of this article (doi:10.1007/s00442-010-1746-6) contains supplementary material, which is available to authorized users.

C. Schüepp $(\bowtie) \cdot$ J. D. Herrmann · M. H. Schmidt-Entling Institute of Ecology and Evolution, Community Ecology, University of Bern, Baltzerstrasse 6, 3012 Bern, Switzerland e-mail: christof.schueepp@iee.unibe.ch

\section{F. Herzog}

Agroscope Reckenholz-Tänikon, Reckenholzstrasse 191, 8046 Zurich, Switzerland
Keywords Habitat fragmentation - Hymenoptera . Landscape ecology $\cdot$ Parasitism $\cdot$ Spatial scale

\section{Introduction}

Progress in the study of habitat fragmentation is complicated by the multiple ways in which fragmentation can be measured (McGarigal and Cushman 2002; Tscharntke et al. 2002; Fahrig 2003; Ewers and Didham 2006; Lindenmayer and Fischer 2007). In particular, there is a need to separate between habitat loss and fragmentation per se, defined as the process of habitats breaking apart independent of the reduction of size. Because fragmentation and loss of habitats are often strongly correlated (Fahrig 2003; Smith et al. 2009) effects of fragmentation can be masked or enhanced by habitat loss and vice versa (Ewers and Didham 2006). The separation of fragmentation and habitat loss is becoming more and more popular in experimental model systems (Grez et al. 2004; Zaviezo et al. 2006; Diekötter et al. 2007; Haynes et al. 2007) but has rarely been achieved in landscape-scale studies (but see Brosi et al. 2008; Farwig et al. 2009; Holzschuh et al. 2010; Bailey et al. 2010). However, population and community ecology need a large-scale perspective because local patterns of biodiversity are influenced by the regional settings (McGarigal and Cushman 2002; Tscharntke and Brandl 2004). Therefore, we tested the effects of local patch isolation (one important aspect of habitat fragmentation per se) and habitat amount (habitat loss) at the landscape scale. We achieved independence of the two factors through the establishment of experimental habitat patches at locations that were selected following a GIS-based landscape analysis. To fully separate landscape-scale habitat amount from patch isolation, the distances by which patches were 
isolated had to be lower than the chosen landscape radius. However, we chose the highest possible isolation distances that still allowed for an independent gradient of landscapescale habitat amount (see "Materials and methods" for details).

It is generally accepted that habitat loss has negative effects on biodiversity and that the amount of suitable habitat in the landscape enhances species richness (Findlay and Houlahan 1997; Wettstein and Schmid 1999; Gurd et al. 2001; Steffan-Dewenter 2002) and abundance (Hargis et al. 1999; Best et al. 2001; Gibbs and Stanton 2001; Schmidt et al. 2008). The effect of habitat isolation on biodiversity is less clear. Increasing isolation from natural source habitats can be associated with a decline or an increase in species richness and abundance (Ewers and Didham 2006; Jauker et al. 2009). Finally, the relationship can also be absent (Krauss et al. 2003; Tylianakis et al. 2006). One likely reason for these conflicting results is that many empirical studies have examined a combined effect of habitat loss and fragmentation as discussed above. Furthermore, species with different traits may differ in their susceptibility to isolation (Ewers and Didham 2006). In particular, predators and parasites of higher trophic levels may suffer more from isolation than their hosts or prey (Tscharntke et al. 1998, 2008; Davies et al. 2000; Albrecht et al. 2007a; Bailey et al. 2010) due to their smaller and more variable populations (Pimm 1991; Kruess and Tscharntke 1994). There is an increasing concern that the disproportional loss of higher trophic ranks in highly simplified agricultural landscapes leads to modified and disrupted ecological functions (Larsen et al. 2005; Tscharntke et al. 2005; Kremen et al. 2007). As a consequence, important ecosystem services such as biological pest control may be at risk.

Diversity patterns and biotic interactions are often driven by processes that are not confined to a single local habitat patch (Tscharntke et al. 2005) and many species in farmland depend on complementary resources from different habitat types to complete their life cycle (Dunning et al. 1992; Klein et al. 2004). In open agricultural landscapes, woody habitats are subject to minimal disturbance and are often the closest potential alternative to natural vegetation, making them important source habitats. Many open land organisms depend on woody structures (Duelli and Obrist 2003; Kremen et al. 2004; Holzschuh et al. 2009; Sanderson et al. 2009). Therefore, biodiversity and ecosystem functions (Kremen et al. 2004; Klein et al. 2007; Farwig et al. 2009) in open agricultural landscapes are strongly influenced by woody habitats.

Here, we studied the abundance, species richness, and Simpson's diversity (Simpson's $D$ ) of cavity-nesting bees and wasps, and their natural enemies. We tested the independent effects of amount of woody habitat in the landscape and three levels of isolation from the next woody habitat (patch isolation) on the colonisation of newly established nesting sites at 30 locations. We hypothesized that abundance, species richness, and diversity decrease with patch isolation and increase with amount of woody habitat at the landscape scale. We expected responses to habitat amount via the direct reduction of population sizes and responses to increased isolation via reduced colonisation rates (Hanski and Gaggiotti 2004). Further, we hypothesized higher trophic ranks to respond more strongly to changes in habitat amount and patch isolation, leading to reduced parasitism rates at isolated sites and in landscapes with low amounts of woody habitat (Tscharntke et al. 1998).

\section{Materials and methods}

\section{Study sites and experimental design}

The study was conducted in the Swiss plateau between the cities Bern, Solothurn, and Fribourg, where agricultural areas are interspersed with forest. We used spatially separated landscape sectors distributed over an area of $23 \times 32 \mathrm{~km}$ and varying in altitude between 465 and $705 \mathrm{~m}$ above sea level. The 30 experimental sites consisted of 18-m-long rows of seven 4-year-old cherry trees that were planted on permanent grassland and managed in a standardised manner (the same sites as in Farwig et al. 2009). The sites were selected according to their percentage of woody habitat cover in a 500-m radius and their level of local isolation. Woody habitats comprised shrubs, hedgerows, orchards, trees, and forest. The percentage of these habitat types in a 500-m radius around the sites varied from 4 to $74 \%$. Isolation had three levels: ten of the sites were located at the edge of dense and tall-growing forest to represent no isolation from natural habitat (edge). The remaining 20 sites were located in a distance of 100-200 m from the next forest, half of them connected by small-sized woody habitats such as hedgerows or single trees (connected) and the other half isolated from any woody habitat by $100-200 \mathrm{~m}$ (isolated). Isolation distances were chosen at a smaller spatial scale than the landscape sector $(500 \mathrm{~m})$ in order to gain independence of the two factors. Information on woody habitats was derived from official digital land-use maps (vector25, swisstopo, Wabern) and verified using aerial photographs and field inspection. There was no statistical dependency between the percentage of woody habitat cover and the level of isolation $\left(F_{2,27}=0.004\right.$, $P>0.99)$. Sites with different levels of isolation and with different percentages of woody habitat in the surrounding landscape were spatially interspersed $(P>0.19$ for relationships of $x$ and $y$ coordinates with isolation and 
percentage of woody habitat, respectively). Coordinates of study sites, level of local isolation, and percentage of woody habitat are provided in Online Resource 1.

\section{Additional variables}

To avoid possible confounding effects, we recorded additional environmental variables that may be correlated with the percentage of woody habitats or habitat isolation. These included the percentage of open near-natural habitats in the landscape (Steffan-Dewenter 2002), altitude, local temperature and humidity (Ewers and Didham 2006), and local species richness of plants (Tscharntke et al. 1998; Albrecht et al. 2007b). Mean temperature ( $d f=28, r=-0.45, P=$ $0.012)$ was negatively and altitude $(d f=28, r=0.38$, $P=0.036)$ positively correlated with the percentage of woody habitat. The remaining additional variables were not correlated with the percentage of woody habitats or habitat isolation and were therefore not included in the analysis. See Online Resource 2 for the non-significant relationships and explanation on how additional variables were measured.

\section{Trap nests}

Two trap nests (Tscharntke et al. 1998; Albrecht et al. 2007a) per site were fixed on wooden posts $1 \mathrm{~m}$ above ground at $6 \mathrm{~m}$, respectively, 12-m distance from one end of the tree rows (next to trees number 3 and 5). Trap nests consisted of plastic tubes (diameter $10 \mathrm{~cm}$, length $20 \mathrm{~cm}$ ) containing approximately 170 internodes of common reed Phragmites australis Trin. The diameter of the internodes ranged from 2 to $10 \mathrm{~mm}$ with similar proportions of different diameters in all trap nests. Trap nests were installed in the field at the beginning of April 2008 and collected mid-October 2008. Trap nests were stored at $5^{\circ} \mathrm{C}$ from mid-October 2008 until mid-January 2009, and single reed internodes were transferred into glass tubes. Tubes were maintained at room temperature $\left(22^{\circ} \mathrm{C}\right)$ from mid-January 2009 to mid-March 2009, and emerged adults sent to specialists for identification. Trap-nesting bees and wasps (Apidae, Pompilidae, Crabronidae, and Eumeninae) and Hymenopteran predators (Chrysididae) were determined to species level, whereas Hymenopteran parasitoids (Braconidae, Ichneumonidae, and Chalcidoidea), Coleopterans, and Dipterans were determined as far as possible and then separated into morphospecies (Table 1). In some cases, no adults emerged and only the genus (or the subfamily in the case of Eumeninae) could be identified using characters of the breeding cell (Gathmann and Tscharntke 1999). These nests were included in the analyses of abundance but only counted as additional species if no other species of the same genus (or subfamily) were found at the site (Holzschuh et al. 2009). Species richness was defined as the total number of species per site. Host abundance was the total number of host cells produced. As both solitary (one parasitoid individual per host individual) and gregarious (multiple parasitoid individuals per host individual) parasitoids were reared, enemy abundance was defined as the number of host cells attacked (Tylianakis et al. 2007).

Simpson's $D$ was calculated as a diversity measure that is independent of the total number of individuals found at a site (Lande 1996). Simpson's $D$ was calculated after the equation $D=1-\sum_{i=1}^{S} p_{i}^{2}$, whereby $S$ is the number of species present at a site and $p_{i}$ is the number of individuals of species $i$ divided by the total number of individuals present at the respective site. $D$ represents the probability that two randomly drawn individuals belong to different species. As such, $D+1$ corresponds to a rarefaction to two individuals (Oksanen 2010). We also calculated rarefied species richness (rarefaction to ten individuals). However, rarefied richness strongly resembled Simpson's $D(r>0.95)$, and the results with respect to habitat isolation and landscape composition were qualitatively the same. Consequently, we display only the results for Simpson's $D$. Parasitism rate was defined as the number of host cells attacked by parasitoids and insect predators, divided by the total number of host cells per site. Mortality rate was the number of other dead cells (where death was caused by other factors than parasitism or insect predation), divided by the total number of host cells.

\section{Statistical analysis}

The data were analysed with generalized linear models. Gaussian error distribution was used to test for effects of woody habitat cover and local isolation (categorical variable with tree levels) on Simpson's $D$, mortality, and parasitism rate (all three arcsin square-root transformed). Quasi-Poisson error distribution (appropriate for count data in the presence of overdispersion) was used to test for effects of percentage of woody habitat and local isolation on species richness and abundance. The percentage of woody habitat was square-root transformed to normalise the residuals. Local flower diversity, percentage of seminatural habitats and humidity were omitted from the analyses because they did not correlate with our two main variables woody habitat cover and patch isolation. Temperature, altitude and the interaction between woody habitat cover and local isolation were first included in the models but then removed because they were not significant in any model. Residuals were tested for adherence to normal distribution and homoscedasticity of variance. All analyses were done with $\mathrm{R}$ version 2.7.1 (R Development Core Team 2005). 
Table 1 Numbers of brood cells of bees and wasps, and numbers of cells attacked by their enemies (parasitoids and insect predators) in 60 trap nests at 30 study sites

\begin{tabular}{|c|c|c|c|}
\hline Nesting species & Number of brood cells & Enemy species & Number of cells attacked \\
\hline Apidae & & Chrysididae & \\
\hline Chelostoma florisomne & 90 & Chrysis cyanea & 110 \\
\hline Chelostoma sp. & 37 & Chrysis ignita & 21 \\
\hline Heriades truncorm & 3 & Chrysis indigotea & 8 \\
\hline Hylaeus communis & 21 & Chrysis cf. mediadentata & 4 \\
\hline Hylaeus difformis & 56 & Omalus aenus & 1 \\
\hline Hylaeus sp. & 26 & Omalus pusillus & 5 \\
\hline Megachile versicolor & 2 & Omalus auratus & 3 \\
\hline Osmia bicornis (rufa) & 708 & Chrysididae sp. & 25 \\
\hline Osmia brevicornis & 14 & Sapygidae & \\
\hline Osmia caerulescens & 9 & Sapyga clavicornis & 10 \\
\hline \multirow[t]{2}{*}{ Osmia sp. } & 37 & & \\
\hline & & Braconidae & \\
\hline Pompilidae & & Braconidae sp. 1-6 $6^{\mathrm{a}}$ & 10 \\
\hline Agenioides cinctellus & 11 & Ichneumonidae & \\
\hline Auplopus carbonarius & 12 & Ephialtes cf. manifestator & 3 \\
\hline Dipogon variegatus & 16 & Stenarella domator & 3 \\
\hline Dipogon subintermedius & 1 & Banchinae sp. & 1 \\
\hline \multirow[t]{2}{*}{ Pompilidae sp. } & 11 & Campopleginae sp. $1-6^{\mathrm{a}}$ & 28 \\
\hline & & Cryptinae sp. $1-3^{\mathrm{a}}$ & 4 \\
\hline \multicolumn{4}{|l|}{ Crabronidae (Sphecidae s.l.) } \\
\hline Passaloecus gracilis & 50 & Eulophidae & \\
\hline Passaloecus corniger & 7 & Chaenotetrastichus semiflavus & 1 \\
\hline Passaloecus eremita & 2 & Kocourekia debilis & 1 \\
\hline Passaloecus sp. & 33 & Melittobia acasta & 229 \\
\hline Pemphedron lugubris & 9 & Eurytomidae & \\
\hline Psenulus fuscipennis & 8 & Eurytomidae sp. & 5 \\
\hline Stigmus pendulus & 1 & Torymidae & \\
\hline Trypoxylon figulus & 1,731 & Monodontomerus sp. & 2 \\
\hline Trypoxylon clavicerum & 20 & & \\
\hline Trypoxylon minus & 8 & Bombyliidae & \\
\hline Trypoxylon sp. & 428 & cf. Anthrax anthrax & 32 \\
\hline \multirow[t]{2}{*}{ Crabronidae sp. } & 20 & Drosophilidae & \\
\hline & & cf. Cacoxenus indagator & 43 \\
\hline Eumeninae & & Tachinidae & \\
\hline Allodynerus rossii & 138 & Tachinidae sp. 1 and $2^{\mathrm{a}}$ & 4 \\
\hline Ancistrocerus nigricornis & 23 & Diptera & \\
\hline Ancistrocerus gazella & 31 & Diptera sp. $1-3^{\mathrm{a}}$ & 8 \\
\hline Ancistrocerus parietinus & 18 & & \\
\hline Microdynerus timidus & 12 & Cleridae & \\
\hline Microdynerus nugdunensis & 2 & cf. Trichodes alvearius & 6 \\
\hline Symmorphus gracilis & 16 & Dermestidae & \\
\hline Eumeninae sp. & 429 & cf. Megatoma undata & 1 \\
\hline Undetermined & 192 & Undetermined & 22 \\
\hline Total of brood cells & 4,232 & Total of attacked cells & 590 \\
\hline
\end{tabular}

a Morphospecies 


\section{Results}

In 60 traps, a total of 1,254 nests with 4,232 individual brood cells of 32 solitary nesting Hymenoptera species were found: eight species of bees (Apidae), 13 species of digger wasps (Crabronidae), seven species of mason wasps (Eumeninae) and four species of spider wasps (Pompilidae) (Table 1). The most abundant family were digger wasps with $55 \%$ of all brood cells, followed by bees $(24 \%)$, mason wasps $(16 \%)$ and spider wasps $(1 \%$; in $5 \%$ of all brood cells the host family could not be determined). The digger wasp Trypoxylon figulus L. was the most abundant species with $40 \%$ of all brood cells, followed by the bee Osmia bicornis L. (17\% of brood cells). Forty-two species of natural enemies attacked 595 brood cells (14\% of all brood cells) (Table 1). The most abundant enemy was the generalist parasitoid Melittobia acasta Walker (Hymenoptera: Eulophidae) accounting for $39 \%$ of all attacked brood cells. The gold wasp Chrysis cyanea L. (Hymenoptera: Chrysididae, 19\%) was found only in nests of T. figulus whereas the fly Cacoxenus indagator Loew (Diptera: Drosophilidae, 7\%) was found only in nests of O. bicornis.

\section{Habitat amount}

The percentage of woody habitats at the landscape scale enhanced species richness (Fig. 1a) and Simpson's $D$ (Fig. 1b) of wasps. At sites with high percentages of woody habitats, species richness of wasps was more than doubled and Simpson's $D$ more than 3 times higher compared to sites with low percentages of woody habitats. In contrast, abundances of wasps tended to decrease with the increasing percentage of woody habitat (Fig. 1c). Neither bees nor enemies were significantly influenced by the percentage of woody habitats at the landscape scale $\left(\left|t_{1,26}\right|<1.5, P>0.15\right)$. Also parasitism and mortality showed no significant response to the percentage of woody habitats at the landscape scale $\left(\left|t_{1,26}\right|<0.8, P>0.42\right)$.

\section{Isolation}

Wasps and natural enemies responded significantly to local patch isolation, showing reduced species richness and abundance with increasing patch isolation (Fig. 2a-d). Bee richness and abundance did not significantly vary with respect to patch isolation (Fig. 2e, f). Simpson's $D$ of wasps, bees and enemies did not change significantly with isolation $\left(F_{2,26}<0.8, P>0.46\right)$. Parasitism rate declined with the level of isolation, being only half as high $(8.5 \%)$ in isolated patches as at forest edges (17\%; Fig. $2 \mathrm{~g})$. In contrast, mortality rate was not influenced by patch isolation $\left(F_{2,26}=0.6, P=0.55\right)$.
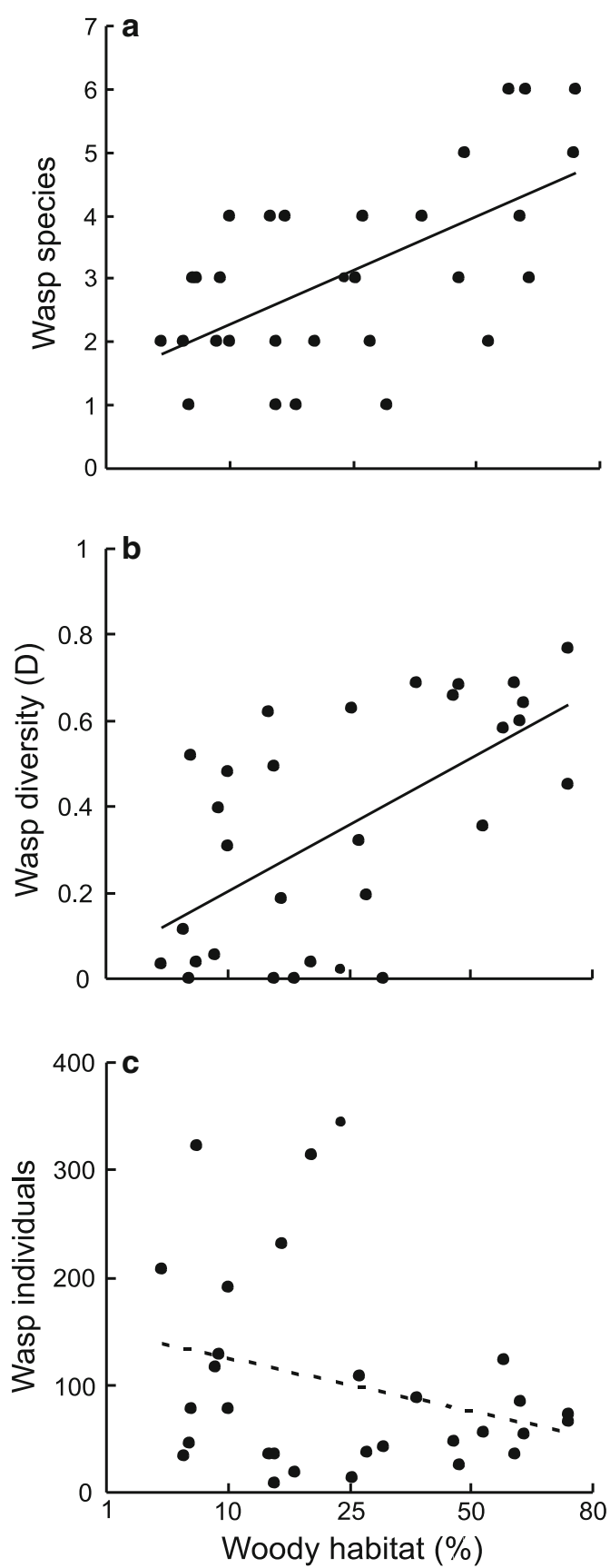

Fig. 1 Effects of the percentage of woody habitats in a 500-m radius on a species richness $\left(t_{1,26}=4.6, P<0.001\right)$, b Simpson's diversity (Simpson's $\left.D ; t_{1,26}=3.6, P=0.001\right)$, and c abundance $\left(t_{1,26}=\right.$ $-2.0, P=0.060)$ of trap-nesting wasps

\section{Discussion}

\section{Effects on wasps}

Species richness of cavity-nesting wasps was independently affected by both the amount of woody habitat in the landscape and by local patch isolation (Figs. 1, 2). Habitat amount enhanced only species richness and Simpson's $D$, 
Fig. 2 Effects of patch isolation on a species richness $\left(F_{2,26}=4.2, P=0.018\right)$ and b abundance $\left(F_{2,26}=8.5\right.$, $P=0.001)$ of wasps, $\mathbf{c}$ species richness $\left(F_{2,26}=5.0\right.$,

$P=0.015)$ and $\mathbf{d}$ abundance

$\left(F_{2,26}=6.9, P=0.004\right)$ of enemies, e species richness $\left(F_{2,26}=1.4, P=0.27\right)$ and f abundance $\left(F_{2,26}=0.73\right.$, $P=0.49)$ of bees, and on g parasitism rate $\left(F_{2,26}=4.0\right.$, $P=0.031)$. Sites were either adjacent to forest (Edge), connected to forest by smallsized woody habitats (Connected), or isolated from all woody habitats by at least $100 \mathrm{~m}$ (Isolated). Mean $\pm \mathrm{SE}$ are shown. Grey bars indicate significant, white bars nonsignificant effects. Capital letters indicate the significance of pairwise differences between levels of habitat isolation
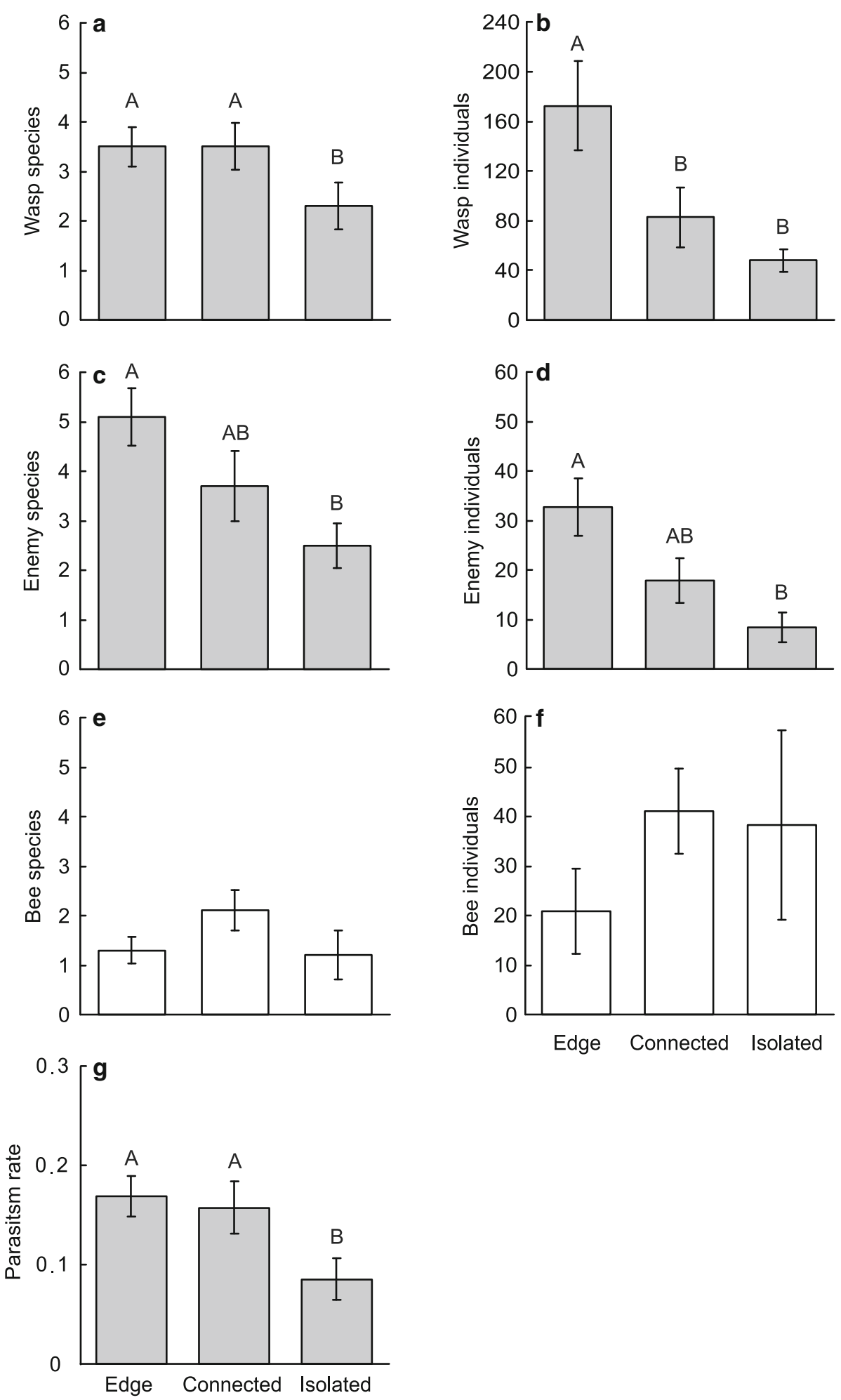

without increasing wasp abundances. In contrast, habitat isolation reduced species richness and wasp abundances, without changing Simpson's $D$. Thus, habitat amount influenced diversity per se, while habitat isolation reduced species richness through individual numbers. This indicates that landscapes with high percentages of woody habitats have higher species pools (Zobel 1997). Contrarily, the negative impact of habitat isolation does not indicate lower overall species richness in the landscape, but reflects reduced numbers of individuals that colonise the local site. 
The impact of isolation from woody habitat is consistent with studies from temperate (Holzschuh et al. 2009) and tropical ecosystems (Tylianakis et al. 2005; Klein et al. 2006). However, patch isolation was not independent of habitat amount in these previous studies. Therefore, the negative effect of increasing isolation could have been caused by the decreasing amount of habitat in the surrounding landscape (Ewers and Didham 2006). Fahrig (2003) suggested that conservation actions that attempt to minimize fragmentation (for a given habitat amount) may often be ineffective. As patch isolation and landscape composition had independent effects in our study, we conclude that both landscape-scale habitat amount and local patch connectivity are simultaneously important for conservation of biodiversity. Due to the widespread correlations between habitat amount and isolation, this recommendation has been so far difficult to make (Tscharntke et al. 2005).

Wasp species richness in sites next to connecting elements, such as hedges or single trees, was similar to that in sites next to forest edges (Fig. 2a), demonstrating the potential of habitat corridors to compensate for the isolation from forest. Nevertheless, the independent effect of habitat amount indicates that connectivity elements are not able to fully mitigate the negative effects of habitat loss at the landscape scale (Harrison and Bruna 1999; Fahrig 2003). In conclusion, our results confirm that woody habitats play an important role in population dynamics of wasps in agricultural landscapes (Tscharntke et al. 1998). Especially larger woody habitats like forest edges may serve as starting points for the colonisation of new habitat patches (Holzschuh et al. 2009).

\section{Differential effects on bees and wasps}

Habitat isolation and the percentage of woody habitats at the landscape scale affected species richness of wasps but showed no significant influence on bees (Figs. 1, 2). Both groups depend on woody habitats for nesting. Therefore, differences between bees and wasps may result either from their different trophic level, from differences in dispersal abilities or from the different role of woody habitats as foraging sites (Steffan-Dewenter 2002). While bees feed exclusively on plant resources, the investigated wasps provision their brood with herbivore or carnivore arthropods and are thus one to two trophic levels higher than bees. However, wasp populations were larger than bee populations. This contrasts with the assumption of decreasing population sizes with trophic level, which underlies the prediction of a corresponding increase of vulnerability towards habitat isolation (Kruess and Tscharntke 1994). Correspondingly, increasing vulnerability to habitat isolation with trophic level may be more relevant for subsequent trophic ranks within a given food web (e.g. hosts and enemies in the current study) than for species from largely separated food webs. Dispersal ability of flying arthropods is commonly estimated by body size because larger species are assumed to have better flight capabilities (Gathmann et al. 1994; vanNieuwstadt and Iraheta 1996; Steffan-Dewenter and Tscharntke 1999, 2000). The mean body length did not differ significantly between the studied bee and wasp species (average body length per species from literature and own measurements: $\left.t_{1,26}=1.29, P=0.21\right)$. This suggests that in this study, dispersal abilities of bees and wasps could have been similar. In contrast, woody habitats may play different roles as foraging sites of bees and wasps. Bees may find highest pollen availability in open habitats, whereas wasps may find highest abundances of prey in woody habitat. We dissected ten nests of the most common wasp T. figulus L. and determined spider species (prey). We found a wide variety of spiders, including one open land (Mangora acalypha) and one generalist species (Theridion impressum), but mostly tree-dwelling species (Araniella sp., Cyclosa conica, Nuctena umbratica, Philodromus sp.). This demonstrates a certain flexibility of wasps in prey choice. However, cells at forest edges, where wasps have the choice between open land and woody habitat, contained almost exclusively spiders living in woody habitats. This indicates that in contrast to bees, wasps may indeed benefit from the proximity of woody habitats for foraging. As bees show different, often species-specific pollen preferences to provision their nests, their abundances can probably only be explained in the presence of more detailed knowledge of their foraging habitats (Cane 2001). A recent study from Costa Rica also found no effect of patch isolation on bee abundance or diversity, and a change in community composition rather than in abundance or diversity with increasing forest cover in the surrounding landscape (Brosi et al. 2008). The difference between bees and wasps in terms of their responses to habitat fragmentation showed how difficult generalisations across different taxonomic groups can be (Ewers and Didham 2006).

\section{Isolation effects on parasitism}

Parasitism and predation by insects (hereafter "parasitism") were a major source of mortality (42\% of all dead cells) and were reduced from $17 \%$ at forest edges to $8.5 \%$ in isolated patches (Fig. $2 \mathrm{~g}$ ). This reduction by half in only 100-200 $\mathrm{m}$ isolation from source habitat (forest edge) is stronger than previous findings (Tscharntke et al. 1998; Klein et al. 2006; Albrecht et al. 2007a). Our findings of a lower parasitism rate in isolated patches contradict the suggestion that natural enemies are highly mobile and not limited by habitat connectivity (Steffan-Dewenter and 
Schiele 2008). This result indicates that habitat isolation may release arthropods from control by their natural enemies. It underlines the role of habitat connectivity for preserving ecosystem functions in farmland, which is in accordance with other negative effects of isolation on pollination, seed predation and insect scavenging (Farwig et al. 2009).

\section{Conclusion}

In conclusion, our study is one of the first landscapescale investigations to show that habitat loss and isolation have independent negative effects on species diversity. In accordance with the trophic level hypothesis, natural enemies of trap-nesting bees and wasps were more strongly affected by habitat isolation than their hosts. This suggests that population regulation of hosts by their enemies can be weakened by habitat fragmentation.

Acknowledgments We are grateful to 30 farmers for providing land for study sites. We thank Jochen Krauss, Nina Farwig, Matthias Albrecht, Florian Menzel and three anonymous reviewers for valuable comments on the manuscript. Suse Schiele and Matthias Albrecht gave important advice on construction and evaluation of trap nests and Ruth Schüepp, Liselotte Looser and Martin Müller assisted in the field and laboratory. We are grateful to Erich Szerencsits and Beatrice Schüpbach for assistance in GIS analysis and Serge Buholzer for mapping plant species. Irene Salzmann (Crabronidae), Mike Herrmann (Eumeninae, Apidae), Hannes Baur (Chalcidoidea), and Seraina Klopfstein (Ichneumonoidea) determined species. This study was supported by the Swiss National Science Foundation under grant number 3100A0-114058 to Felix Herzog and Martin Schmidt-Entling.

\section{References}

Albrecht M, Duelli P, Schmid B, Müller CB (2007a) Interaction diversity within quantified insect food webs in restored and adjacent intensively managed meadows. J Anim Ecol 76: $1015-1025$

Albrecht M, Duelli P, Müller C, Kleijn D, Schmid B (2007b) The Swiss agri-environment scheme enhances pollinator diversity and plant reproductive success in nearby intensively managed farmland. J Appl Ecol 44:813-822

Bailey D, Schmidt-Entling MH, Eberhart P, Herrmann J, Hofer G, Kormann U, Herzog F (2010) Effects of habitat amount and isolation on biodiversity in fragmented traditional orchards. J Appl Ecol. doi:10.1111/j.1365-2664.2010.01858.x

Best LB, Bergin TM, Freemark KE (2001) Influence of landscape composition on bird use of rowcrop fields. J Wildl Manage 65:442-449

Brosi BJ, Daily GC, Shih TM, Oviedo F, Durán G (2008) The effects of forest fragmentation on bee communities in tropical countryside. J Appl Ecol 45:773-783

Cane JH (2001) Habitat fragmentation and native bees: a premature verdict? Conserv Ecol 5:3

Davies KF, Margules CR, Lawrence KF (2000) Which traits of species predict population declines in experimental forest fragments? Ecology 81:1450-1461
Diekötter T, Haynes KJ, Mazeffa D, Crist TO (2007) Direct and indirect effects of habitat area and matrix composition on species interactions among flower-visiting insects. Oikos 116:1588-1598

Duelli P, Obrist MK (2003) Regional biodiversity in an agricultural landscape: the contribution of seminatural habitat islands. Basic Appl Ecol 4:129-138

Dunning JB, Danielson BJ, Pulliam HR (1992) Ecological processes that affect populations in complex landscapes. Oikos 65:169-175

Ewers RM, Didham RK (2006) Confounding factors in the detection of species responses to habitat fragmentation. Biol Rev 81:117-142

Fahrig L (2003) Effects of habitat fragmentation on biodiversity. Annu Rev Ecol Evol Syst 34:487-515

Farwig N, Bailey D, Bochud E, Herrmann J, Kindler E, Reusser N, Schüepp C, Schmidt-Entling MH (2009) Isolation from forest reduces pollination, seed predation and insect scavenging in Swiss farmland. Landsc Ecol 24:919-927

Findlay CS, Houlahan J (1997) Anthropogenic correlates of species richness in southeastern Ontario wetlands. Conserv Biol 11:1000-1009

Gathmann A, Tscharntke T (1999) Landschafts-Bewertung mit Bienen und Wespen in Nisthilfen: Artenspektrum, Interaktionen und Bestimmungsschlüssel. Natursch Landschaftspfl BadenWürtt 73:277-305

Gathmann A, Greiler HJ, Tscharntke T (1994) Trap-nesting bees and wasps colonizing set-aside fields-succession and body size, management by cutting and sowing. Oecologia 98:8-14

Gibbs JP, Stanton EJ (2001) Habitat fragmentation and arthropod community change: carrion beetles, phoretic mites, and flies. Ecol Appl 11:79-85

Grez AA, Zaviezo T, Reyes S (2004) Short-term effects of habitat fragmentation on the abundance and species richness of beetles in experimental alfalfa microlandscapes. Rev Chil Hist Nat 77:547-558

Gurd DB, Nudds TD, Rivard DH (2001) Conservation of mammals in eastern North American wildlife reserves: how small is too small? Conserv Biol 15:1355-1363

Hanski I, Gaggiotti OE (2004) Ecology, genetics, and evolution of metapopulations. Elsevier Academic Press, San Diego

Hargis CD, Bissonette JA, Turner DL (1999) The influence of forest fragmentation and landscape pattern on American martens. J Appl Ecol 36:157-172

Harrison S, Bruna E (1999) Habitat fragmentation and large-scale conservation: what do we know for sure? Ecography 22:225-232

Haynes KJ, Diekötter T, Crist TO (2007) Resource complementation and the response of an insect herbivore to habitat area and fragmentation. Oecologia 153:511-520

Holzschuh A, Steffan-Dewenter I, Tscharntke T (2009) Grass strip corridors in agricultural landscapes enhance nest-site colonization by solitary wasps. Ecol Appl 19:123-132

Holzschuh A, Steffan-Dewenter I, Tscharntke T (2010) How do landscape composition and configuration, organic farming and fallow strips affect the diversity of bees, wasps and their parasitoids? J Anim Ecol 79:491-500

Jauker F, Diekötter T, Schwarzbach F, Wolters V (2009) Pollinator dispersal in an agricultural matrix: opposing responses of wild bees and hoverflies to landscape structure and distance from main habitat. Landsc Ecol 24:547-555

Klein AM, Steffan-Dewenter I, Tscharntke T (2004) Foraging trip duration and density of megachilid bees, eumenid wasps and pompilid wasps in tropical agroforestry systems. J Anim Ecol 73:517-525

Klein AM, Steffan-Dewenter I, Tscharntke T (2006) Rain forest promotes trophic interactions and diversity of trap-nesting hymenoptera in adjacent agroforestry. J Anim Ecol 75:315-323

Klein AM, Vaissiere BE, Cane JH, Steffan-Dewenter I, Cunningham SA, Kremen C, Tscharntke T (2007) Importance of pollinators in 
changing landscapes for world crops. Proc R Soc B Biol 274:303-313

Krauss J, Steffan-Dewenter I, Tscharntke T (2003) How does landscape context contribute to effects of habitat fragmentation on diversity and population density of butterflies? J Biogeogr 30:889-900

Kremen C, Williams NM, Bugg RL, Fay JP, Thorp RW (2004) The area requirements of an ecosystem service: crop pollination by native bee communities in California. Ecol Lett 7:1109-1119

Kremen C, Williams NM, Aizen MA, Gemmill-Herren B, LeBuhn G, Minckley R, Packer L, Potts SG, Roulston T, Steffan-Dewenter I, Vazquez DP, Winfree R, Adams L, Crone EE, Greenleaf SS, Keitt TH, Klein AM, Regetz J, Ricketts TH (2007) Pollination and other ecosystem services produced by mobile organisms: a conceptual framework for the effects of land-use change. Ecol Lett 10:299-314

Kruess A, Tscharntke T (1994) Habitat fragmentation, species loss, and biological control. Science 264:1581-1584

Lande R (1996) Statistics and partitioning of species diversity, and similarity among multiple communities. Oikos 76:5-13

Larsen TH, Williams NM, Kremen C (2005) Extinction order and altered community structure rapidly disrupt ecosystem functioning. Ecol Lett 8:538-547

Lindenmayer DB, Fischer J (2007) Tackling the habitat fragmentation panchreston. Trends Ecol Evol 22:127-132

McGarigal K, Cushman SA (2002) Comparative evaluation of experimental approaches to the study of habitat fragmentation effects. Ecol Appl 12:335-345

Oksanen J (2010) Vegan: ecological diversity. http://CRAN.Rproject.org/package $=$ vegan

Pimm SL (1991) The balance of nature? Ecological issues in the conservation of species and communities. The University of Chicago, Chicago

R Development Core Team (2005) R: a language and environment for statistical computing. R Foundation for Statistical Computing, Vienna. ISBN 3-900051-07-0. http://www.R-project.org

Sanderson FJ, Kloch A, Sachanowicz K, Donald PF (2009) Predicting the effects of agricultural change on farmland bird populations in Poland. Agric Ecosyst Environ 129:37-42

Schmidt MH, Thies C, Nentwig W, Tscharntke T (2008) Contrasting responses of arable spiders to the landscape matrix at different spatial scales. J Biogeogr 35:157-166

Smith A, Koper N, Francis C, Fahrig L (2009) Confronting collinearity: comparing methods for disentangling the effects of habitat loss and fragmentation. Landsc Ecol 24:1271-1285

Steffan-Dewenter I (2002) Landscape context affects trap-nesting bees, wasps, and their natural enemies. Ecol Entomol 27:631-637
Steffan-Dewenter I, Schiele S (2008) Do resources or natural enemies drive bee population dynamics in fragmented habitats? Ecology 89:1375-1387

Steffan-Dewenter I, Tscharntke T (1999) Effects of habitat isolation on pollinator communities and seed set. Oecologia 121:432-440

Steffan-Dewenter I, Tscharntke T (2000) Butterfly community structure in fragmented habitats. Ecol Lett 3:449-456

Tscharntke T, Brandl R (2004) Plant-insect interactions in fragmented landscapes. Annu Rev Entomol 49:405-430

Tscharntke T, Gathmann A, Steffan-Dewenter I (1998) Bioindication using trap-nesting bees and wasps and their natural enemies: community structure and interactions. J Appl Ecol 35:708-719

Tscharntke T, Steffan-Dewenter I, Kruess A, Thies C (2002) Characteristics of insect populations on habitat fragments: a mini review. Ecol Res 17:229-239

Tscharntke T, Klein AM, Kruess A, Steffan-Dewenter I, Thies C (2005) Landscape perspectives on agricultural intensification and biodiversity-ecosystem service management. Ecol Lett 8:857-874

Tscharntke T, Sekercioglu CH, Dietsch TV, Sodhi NS, Hoehn P, Tylianakis JM (2008) Landscape constraints on functional biodiversity in tropical agroecosystems. Ecology 89:944-951

Tylianakis JM, Klein AM, Tscharntke T (2005) Spatiotemporal variation in the diversity of hymenoptera across a tropical habitat gradient. Ecology 86:3296-3302

Tylianakis JM, Klein AM, Lozada T, Tscharntke T (2006) Spatial scale of observation affects $\alpha, \beta$ and $\gamma$ diversity of cavity-nesting bees and wasps across a tropical land-use gradient. J Biogeogr 33:1295-1304

Tylianakis JM, Tscharntke T, Lewis OT (2007) Habitat modification alters the structure of tropical host-parasitoid food webs. Nature 445:202-205

vanNieuwstadt MGL, Iraheta CER (1996) Relation between size and foraging range in stingless bees (Apidae, Meliponinae). Apidologie 27:219-228

Wettstein W, Schmid B (1999) Conservation of arthropod diversity in montane wetlands: effect of altitude, habitat quality and habitat fragmentation on butterflies and grasshoppers. J Appl Ecol 36:363-373

Zaviezo T, Grez AA, Estades CF, Perez A (2006) Effects of habitat loss, habitat fragmentation, and isolation on the density, species richness, and distribution of ladybeetles in manipulated alfalfa landscapes. Ecol Entomol 31:646-656

Zobel M (1997) The relative role of species pools in determining plant species richness. An alternative explanation of species coexistence? Trends Ecol Evol 12:266-269 